\title{
Kajian Daya Dukung Ekowisata Hutan Mangrove Blanakan, Subang, Jawa Barat
}

\section{The Study of Carrying Capacity in Mangrove Ecotourism Blanakan, Subang, West Java}

\author{
Fuad Muhammad $^{1)}$, Sambas Basuni ${ }^{2)}$, Aris Munandar ${ }^{3)}$ dan Herry Purnomo ${ }^{4)}$ \\ 1) JurusanBiologi FSM UNDIP dan Program Doktor Sekolah Pascasarjana IPB \\ Kampus IPB Darmaga, Bogor. Email: fuad_id@yahoo.com \\ ${ }^{2)}$ Departemen Konservasi sumber daya Hutan, Fahutan IPB \\ 3) Departemen Arsitektur Landskap, Faperta IPB \\ 4) Departemen Manajemen Kehutanan, Fahuntan IPB
}

\begin{abstract}
Abstrak
Growth in tourist arrivals at ecotourism mangrove in Blanakan can cause a threat to the preservation of conservation areas and tourist attraction. This happens when the utilization of the region exceeds its carrying capacity. The aims of This study to identify the carrying capacity of ecotourism mangrove in Blanakan as conservation areas are used for tourism activities. The results showed that the carrying capacity the ecotourism mangrove in Blanakan is 425 visitors per day. Pollution load simulation results showed that ecotourism mangrove Blanakan had suffered pollution by phosphate, ammonia pollution carrying capacity will be passed in 2019 and organic waste in the year 2011 to 2013, while nitrate and garbage until the year 2032 has not been exceeded.
\end{abstract}

Key words: ecotourism, mangrove, carrying capacity

\section{PENDAHULUAN}

Obyek wisata yang berada di dalam kawasan hutan lindung, dalam pemanfaatan dan pengembangannya sebagai obyek wisata diatur dalam UU RI No. 9 Tahun 1990 Tentang Konservasi Sumberdaya Alam dan Ekosistem. Kawasan hutan mangrove pantai Blanakan, Subang ditetapkan sebagai Hutan Lindung berdasarkan SK Menteri Kehutanan No. 195/KPTS-II/2003 sehingga pemanfaatan secara materi tidak diperbolehkan dilakukan di kawasan ini. Oleh karena itu diupayakan pemanfaatan lain dalam bentuk ekowisata mangrove yang dikelola dengan bijaksana. Hal ini sesuai dengan Peraturan Daerah (Perda) Kabupaten Subang No. 2 Tahun 2004, bahwa Rencana Tata Ruang Wilayah Kabupaten (RTRWK) Subang di wilayah Pantai Blanakan adalah untuk pengembangan ekowisata mangrove.

Dari data kunjungan wisatawan ke Blanakan tahun 2003-2008 dengan jumlah pengunjung antara 5.894-13.860 orang. Hal ini mengindikasikan ekowisata mangrove Blanakan mempunyai potensi untuk dikembangkan menjadi kawasan wisata unggulan. Dengan bertambahnya wisatawan yang berkunjung, maka perlu perencanaan dan pengelolaan obyek dan daya tarik wisata. Perencanaan obyek wisata khususnya yang berada di lokasi yang rentan, harus memperhatikan keterbatasan-keterbatasan lingkungan yang ada.

Beberapa kasus dampak negatif aktivitas wisata pada area konservasi telah terjadi antara lain di taman wisata alam pananjung pangandaran, kegiatan wisata menyebabkan gangguan terhadap biodiversitas flora dan fauna (Sawitri, 2003) dan di taman wisata alam tangkuban perahu yang menyebabkan dampak negatif terhadap kondisi fisik tanah yang mengakibatkan peningkatan erosi (Gertiasih dan Pratiwi, 2003). Beberapa kasus lain, seperti kegiatan wisata di daerah Amazon, Ecuador telah terjadi dampak negatif berupa turunnya biodiversitas akibat adanya perdagangan satwa kepada wisatawan dan perkembangan akomodasi yang mengancam kelestarian lingkungan hidup (Drumm, 1991). Dampak negatif wisata alam di Hongkong pun terjadi akibat limbah yang berasal dari hotel berupa limbah organik, sehingga menyebabkan pencemaran air, tanah dan udara (Jim, 2000). Kasus-kasus yang terjadi merupakan kesalahan dalam pengelolaan yaitu tidak memperhatikan daya dukung kawasan. 
Dalam pengembangan kawasan konservasi menjadi area wisata unggulan perlu mempertimbangkan bahwa kegiatan wisata tidak boleh menyebabkan terganggunya fungsi kawasan konservasi yang diakibatkan oleh pemanfaatan yang melebihi daya dukungnya. Dalam kerangka mengembangkan model pengelolaan taman wisata alam berbasis daya dukung, maka penelitian ini mempunyai tujuan khusus yaitu mengkaji daya dukung kawasan ekowisata mangrove Blanakan dan mengkaji dampak pencemaran akibat aktivitas wisata terhadap komponen daya dukung ekowisata mangrove Blanakan.

\section{BAHAN DAN METODE}

Penelitian akan dilakukan pada bulan Januari 2011 - April 2012 di kawasan ekowisata mangrove Blanakan, Subang, Jawa Barat.

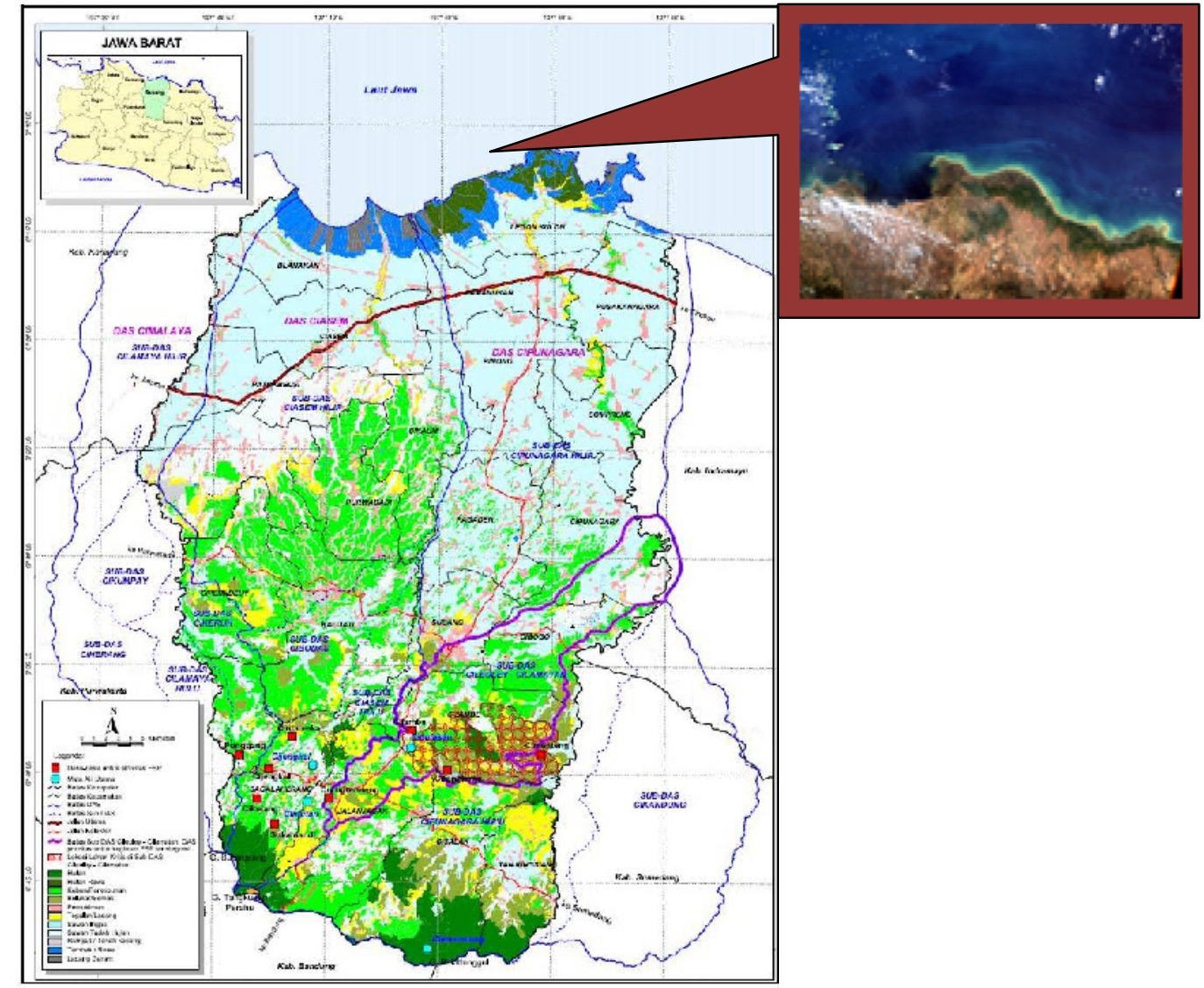

Gambar 1. Lokasi Ekowisata Mangrove Blanakan, Kabupaten Subang Sumber: BPS Kabupaten Subang, 2009

\section{Pengumpulan dan analisis data}

Data yang digunakan adalah data primer dan sekunder yang diperoleh dari responden, pakar dan instansi terkait. Data primer terdiri dari pengunjung ekowisata hutan mangrove Blanakan, aspek fisik kimia dan parameter BOD, DO, konsentrasi phosfat, nitrat, dan amonia di perairan
Sungai Blanakan. Analisis dampak kegiatan wisata terhadap kualitas lingkungan dilakukan dengan penentuan kapasitas asimilasi beban pencemaran menggunakan model Chapra (1983).

Penghitungan daya dukung fisik kawasan terhadap jumlah maksimal pengunjung ditentukan 
dengan menggunakan penghitungan daya dukung fisik menurut Cifuentes (1992).

\section{HASIL DAN PEMBAHASAN}

Hutan mangrove Blanakan mempunyai potensi yang besar untuk dikembangkan sebagai obyek wisata. Hutan mangrove Blanakan mempunyai luas 131,7 ha terletak pada ketinggian 0 - $1 \mathrm{~m}$ dpl., dengan konfigurasi lapangan umumnya datar. Blanakan mempunyai bentuk permukaan tanah berupa dataran dengan produktivitas rendah untuk budidaya pertanian. Hal ini disebabkan salinitas yang tinggi serta tekstur tanah berupa pasir dan tanah liat, sedangkan wilayah perairan pada umumnya berpasir. Keadaan iklim Blanakan berdasarkan Schmidt dan Ferguson bertipe iklim C dan D dengan curah hujan sekitar $63,6 \mathrm{~mm} / \mathrm{bulan}$, yang terjadi pada bulan-bulan normal dengan jumlah hari hujan 100 hari. Bulan basah terjadi antara bulan Desember-Maret, sedangkan bulan lembab April-Juni dan kering antara bulan Juli-Nopember. Iklim pesisir Blanakan dipengaruhi oleh angin muson, dengan kecepatan angin rata-rata 3-5 $\mathrm{m}$ per detik. Secara umum kondisi geologi di Blanakan dibagi menjadi beberapa jenis batuan pembentuk tanah, yaitu sedimen dan miosen fasies sedimen. Jenis tanah di Blanakan terdiri atas beberapa kelompok yakni asosiasi alluvial kelabu \& alluvial coklat kekelabuan.

Potensi yang dimiliki hutan mangrove Blanakan antara lain keindahan vegetasi mangrove dengan tipe perakaran yang unik, adanya zonasi mangrove di sepanjang pantai, penangkaran buaya yang cukup besar. Daya tarik yang lain adalah kekayaan flora dan fauna (satwa) yang berasosiasi dengan ekosistem mangrove. Berbagai atraksi masyarakat dalam memanfaatkan sumberdaya mangrove dan adat istiadat serta upacara adat yang diselenggarakan di Blanakan, yaitu upacara Nadran (pesta laut) dan Sisingaan. Kegiatan wisata lain yang dilakukan di Blanakan adalah berperahu, jalan-jalan (trekking), pengamatan satwa, memancing, berkemah dan taman bermain. Dari berbagai atraksi yang ditawarkan menarik minat kunjungan ke ekowisata mangrove Blanakan. Hal ini dapat dilihat dari jumlah pengunjung yang meningkat dari tahun ke tahun.

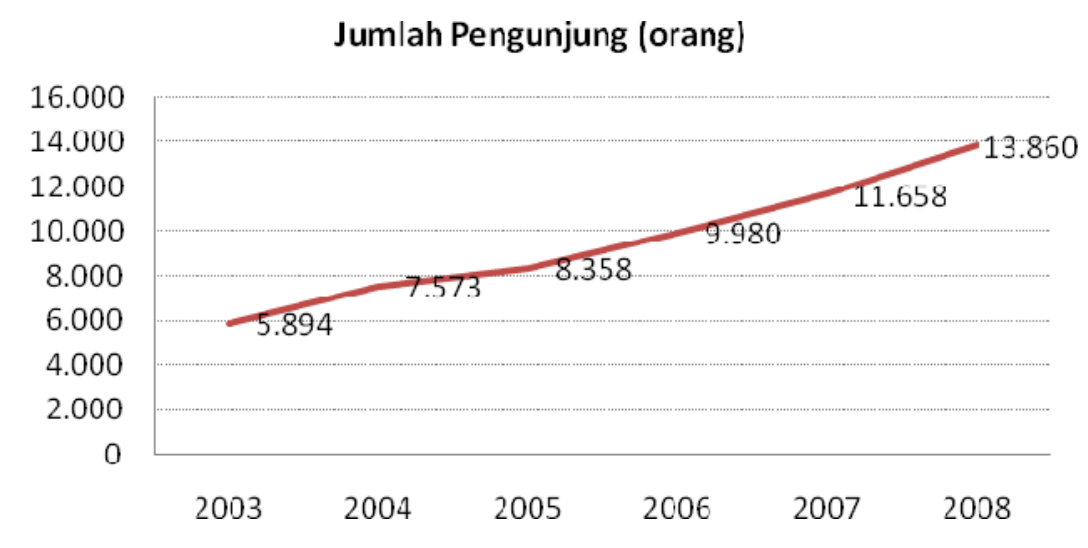

Gambar 1. Jumlah pengunjung ekowisata mangrove Blanakan tahun 2003-2008

\section{Aspek Fisika-Kimia di kawasan ekowisata hutan mangrove Blanakan}

Hasil pengukuran parameter fisika dan kimia perairan yang dilakukan disajikan dalam tabel berikut : 
Tabel 1. Parameter Fisika Kimia Ekosistem Perairan Mangrove Blanakan

\begin{tabular}{llcccc}
\hline \multirow{2}{*}{ Fisika } & \multicolumn{1}{c}{ Parameter } & Unit & St 1 & St 2 & St 3 \\
& Warna Perairan & & Coklat keruh & Coklat keruh & Coklat keruh \\
& Tipe Substrat & & Lumpur halus & Lumpur halus & Lumpur halus \\
& Suhu & ${ }^{0} \mathrm{C}$ & 28,83 & 28,67 & 29 \\
& Kecerahan & $\mathrm{cm}$ & $18-19,5$ & $19-25,5$ & $17-21,5$ \\
& Kedalaman & $\mathrm{cm}$ & 43 & 80 & 60,3 \\
\hline \multirow{2}{*}{ Kimia } & pH & & 7 & 7 & 7 \\
& Salinitas & $\mathrm{ppm}$ & 20 & 20 & 20 \\
\hline
\end{tabular}

Ekosistem mangrove Blanakan dipengaruhi oleh kondisi lingkungan perairan. Intensitas cahaya, suhu, $\mathrm{pH}$, salinitas, dan lain-lain merupakan faktor lingkungan yang harus diperhatikan untuk mendukung pertumbuhan dan produksi mangrove. Hasil pengukuran $\mathrm{pH}$ pada perairan Blanakan adalah 7. Hal ini berarti perairan tersebut mempunyai $\mathrm{pH}$ yang normal. Air payau merupakan penyangga yang baik terhadap perubahan $\mathrm{pH}$ karena pada perairan payau jarang terjadi fluktuasi $\mathrm{pH}$. Umumnya mangrove hidup dan tumbuh dengan baik di daerah estuari dengan kisaran salinitas antara 10-30 ppm. Pada perairan Blanakan nilai salinitas yang diperoleh adalah 20 ppm, maka perairan tersebut masih mempunyai nilai salinitas yang baik.

Cahaya matahari merupakan faktor abiotik yang mutlak diperlukan dalam proses fotosintesis. Dengan demikian produktivitas fitoplankton sangat ditentukan oleh adanya penetrasi cahaya matahari ke dalam kolom air. Nilai kecerahan yang diperoleh dari pengukuran di tiga stasiun berkisar antara $18-19,5 \mathrm{~cm}$ pada stasiun1, $19-25,5 \mathrm{~cm}$ pada stasiun 2, dan $17-21,5 \mathrm{~cm}$ pada stasiun 3. Nilai kecerahan sangat dipengaruhi oleh keadaan cuaca, waktu pengukuran, kekeruhan, dan padatan tersuspensi. Kekeruhan di perairan estuari terjadi karena pencampuran partikel-partikel organik dan endapan halus dari aliran sungai dan laut melalui pergerakan pasang dan surut.

Suhu berperan sebagai pengatur metabolisme dalam perairan. Suhu pada perairan Blanakan berkisar antara $28{ }^{\circ} \mathrm{C}-29{ }^{\circ} \mathrm{C}$. Hal ini berarti suhu pada perairan Blanakan merupakan suhu yang normal untuk perairan mangrove di daerah tropis. Tipe substrat pada perairan Blanakan adalah lumpur, hal ini berarti banyak terdapat bahan organik pada dasar perairan. Tipe substrat juga akan mempengaruhi warna perairan.
Warna perairan pada perairan Blanakan adalah coklat keruh. Hal ini karena tipe substrat pada perairan ini berupa lumpur halus.

\section{Pencemaran perairan di kawasan ekowisata hutan mangrove Blanakan}

Air limbah baik yang diolah ataupun yang tidak diolah apabila masuk ke perairan akan mengalami tekanan oleh ekosistem air. Tekanan tersebut berupa pengurangan atau penghilangan bahan pencemar oleh berbagai proses yang ada dalam air. Proses ini meliputi pengenceran secara fisik, penyebaran, pengendapan, reaksi kimia, adsorbsi, penguraian secara biologis dan stabilisasi. Proses-proses tersebut pada dasarnya merupakan sifat alamiah air yang memiliki kemampuan untuk membersihkan atau menghancurkan berbagai kontaminan dan pencemar yang dibawa air limbah (Abdullah, 2006).

Menurut Imholf (Abdullah, 2006) kemampuan air untuk membersihkan diri secara alamiah dari berbagai kontaminan dan pencemar dikenal sebagai swa pentahiran atau self purification. Kemampuan perairan untuk melakukan pembersihan diri ini dikenal juga dengan istilah kapasitas asimilasi (assimilative capacity). Menurut Krom (Hartomo, 2004) kapasitas asimilasi adalah kemampuan sesuatu ekosistem untuk menerima suatu jumlah limbah tertentu sebelum ada indikasi terjadinya kerusakan lingkungan dan atau kesehatan yang tidak dapat ditoleransi.

Tabel 2 di bawah ini adalah hasil analisis regresi beberapa parameter yang diukur dan menunjukkan besaran kapasitas asimilasi yang dimiliki oleh perairan yang berada di kawasan hutan mangrove Blanakan terhadap beberapa 
parameter yang diukur. Fungsi $\hat{y}$ menunjukkan

pencemaran.

kualitas perairan pada masing-masing stasiun

Tabel 2. Fungsi hubungan konsentrasi pencemar inlet dan outlet di perairan kawasan ekowisata mangrove Blanakan

\begin{tabular}{clcc}
\hline Parameter & \multicolumn{1}{c}{ Fungsi y } & $\mathbf{R}^{\mathbf{2}}$ & $\begin{array}{c}\text { Kapasitas asimilasi } \\
\text { (ton/tahun) }\end{array}$ \\
\hline Ammonia & $\hat{\mathrm{y}}=0,0489 \mathrm{x}+0,1914$ & 0,87 & 280 \\
Nitrat & $\hat{\mathrm{y}}=0,1114 \mathrm{x}+0.0004$ & 0,96 & 1666,67 \\
Fosfat & $\hat{\mathrm{y}}=8.10^{-6} \mathrm{x}+0,1889$ & 0,82 & 9 \\
BOD & $\hat{\mathrm{y}}=0,020 \mathrm{x}+0.027$ & 0,94 & 148,65 \\
\hline
\end{tabular}

Simulasi Pencemaran di perairan kawasan ekowisata hutan mangrove Blanakan

Simulasi pencemaran di perairan kawasan ekowisata mangrove Blanakan digunakan untuk menentukkan prediksi beban pencemar per tahun dari tahun 2003 - 2032. Dalam simulasi pencemaran dipengaruhi oleh kapasitas asimilasi maksimal dan rerata kontribusi pengunjung terhadap pencemaran. Simulasi dilakukan selama 30 tahun. Berikut grafik beban pencemar ammonia, nitrat, fosfat dan BOD pertahun disimulasikan selama 30 tahun dari tahun 2003 2032.

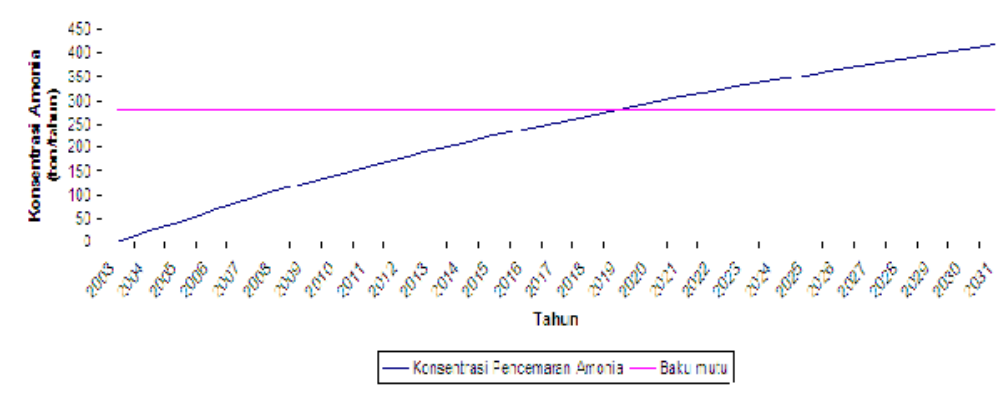

Gambar 2. Simulasi beban pencemar ammonia di perairan kawasan ekowisata hutan mangrove Blanakan tahun 2003-2031

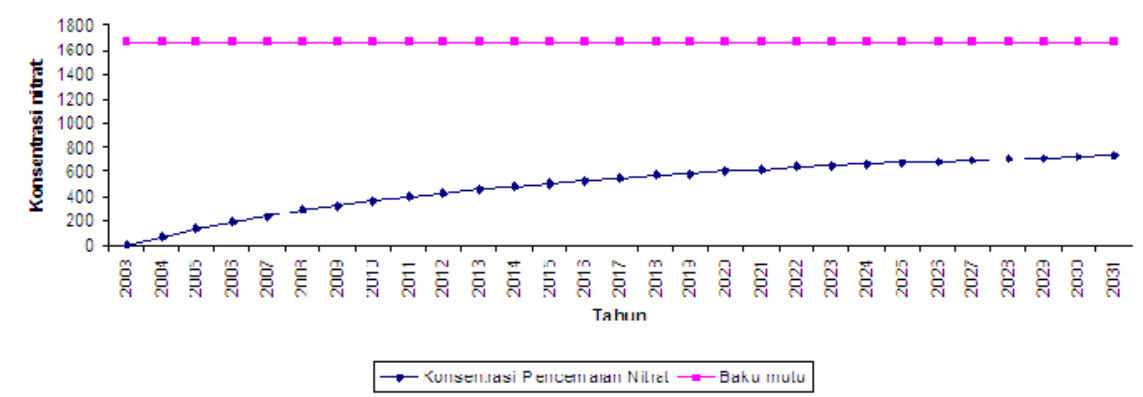

Gambar 3. Simulasi beban pencemar nitrat di perairan kawasan ekowisata hutan mangrove Blanakan tahun 2003-2031 


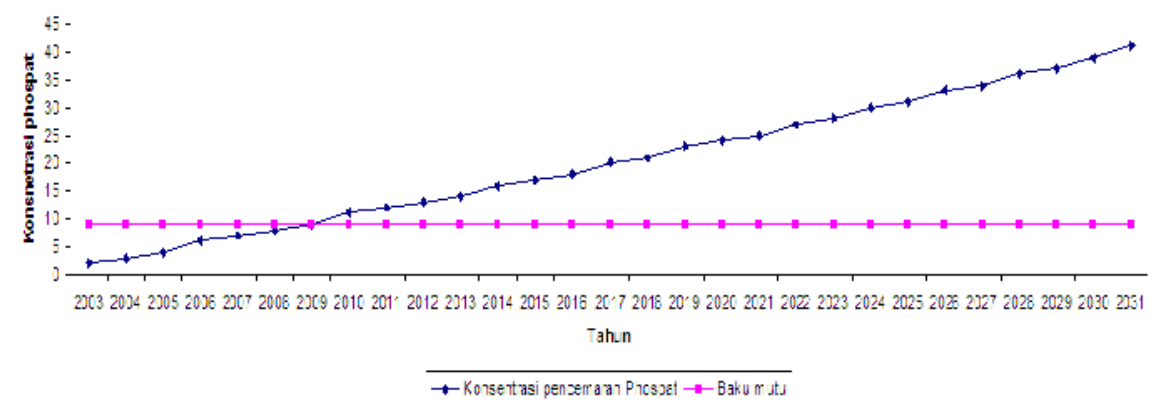

Gambar 4. Simulasi beban pencemar phospat di perairan kawasan ekowisata hutan mangrove Blanakan tahun 2003-2031

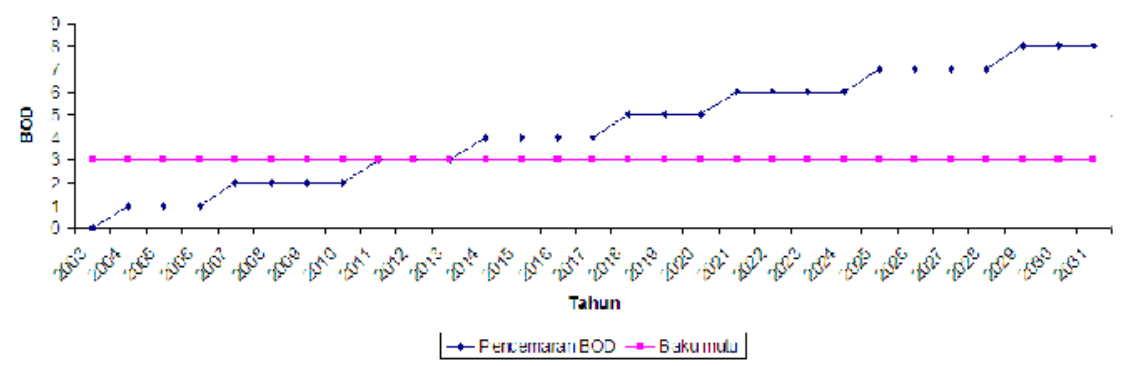

Gambar 5. Simulasi beban pencemar BOD di perairan kawasan ekowisata hutan mangrove Blanakan tahun 2003-2031

Berdasarkan hasil simulasi dapat
ditunjukkan prediksi beban pencemaran
berdasarkan pertumbuhan wisatawan sebagai
berikut: beban pencemaran ammonia di perairan
ekowisata mangrove Blanakan tahun $2003-2019$
tidak menyebabkan terjadi pencemaran dan
pencemaran terjadi setelah tahun 2019. Hal
tersebut disebabkan oleh beban pencemaran
amonia melewati kapasitas asimilasi badan
perairan terjadi setelah tahun 2019. Perairan
ekowisata mangrove Blanakan berdasarkan
pencemar ammonia termasuk kedalam tipe
kelentingan fragile, hal itu dapat ditunjukkan dari
beban pencemar setelah dikurangi kapasitas
asimilasinya melewati baku mutu ammonia yaitu
248 ton/tahun (Gambar 2). Tipe kelentingan nitrat
di perairan mangrove Blanakan bertipe resilience.
Hal ini ditunjukkan dengan beban pencemaran
nitrat setelah dikurangi kapasitas asimilasinya
masih dibawah baku mutu. Kapasitas asimilasi
nitrat sebesar 1666 ton/tahun sedangkan

pencemaran nitrat yang terjadi hanya berkisar dari 74,72 - 133,25 ton/tahun (Gambar 3). Tipe kelentingan fosfat di perairan ekowisata mangrove Blanakan adalah fragile. Pencemaran fosfat sudah tidak dapat diasimilasi lagi sebesar 74,72 ton/tahun dan akan terus meningkat pada tahun berikutnya. Pencemaran fosfat sudah melewati batas baku mutu yang hanya sebesar 9 ton/tahun (Gambar 4). Tipe kelentingan pencemaran limbah organik adalah fragile mulai tahun 2011. hal tersebut terjadi karena beban pencemaran sudah melewati baku mutu yaitu 3 ppm pada tahun 2011 .

\section{Daya dukung kawasan ekowisata mangrove Blanakan}

Daya dukung areal rekreasi didasarkan pada perhitungan luas efektif dibagi dengan kebutuhan areal per orang areal rekreasi, dimana luas efektif yang dicanangkan ekowisata mangrove Blanakan seluas 5 ha. Dengan demikian hasil perhitungan daya dukung kawasan per hari mampu mendukung kegiatan rekreasi 425 orang/hari. 
Kawasan hutan mangrove Blanakan merupakan kawasan konservasi yang mempunyai fungsi lain yaitu sebagai objek wisata alam. Sehubungan dengan fungsi tersebut, pengembangan ekowisata mangrove Blanakan diarahkan pada kegiatan wisata yang tidak bersifat mass tourism. Akan tetapi minat wisatawan terhadap objek wisata alam relatif cukup tinggi pertumbuhannya. Hal tersebut menyebabkan terjadinya penumpukan wisatawan di area tersebut. Penumpukan wisatawan, terutama pada akhir pekan dan hari libur nasional menjadi permasalahan karena menimbulkan stress bagi lingkungan dan juga secara sosial, yaitu timbulnya ketidaknyamanan pengunjung yang dapat menurunkan tingkat kepuasan. Dampak lain dari peningkatan pengunjung adalah daya tarik ekonomi bagi masyarakat sekitar yang datang dan mendirikan bangunan tanpa ijin yang mengakibatkan terjadinya perubahan bentang alam. Untuk mengatasi permasalahan tersebut maka perlu dikembangkan suatu konsep pengelolaan pariwisata berkelanjutan ekowisata mangrove Blanakan.

Untuk memahami konsep keberlanjutan pada kegiatan pariwisata, seperti yang di jelaskan oleh Krecher (2003) yaitu "sustainable tourism as tourism which leads to management of all resources in such a way that economic, social and aesthetic needs can be filled while maintaining cultural integrity, essentials ecological processes, biological diversity and life support systems", masih menimbulkan keberagaman pemahaman. Hal tersebut terjadi karena adanya keberagaman dalam penentuan indikator, aksi, kebijakan dan trade off yang dilakukan tidak konsisten. Untuk memahami konsep keberlanjutan maka kita harus merujuk pada fungsi utama kawasan wisata alam yang merupakan area konservasi. Maka konsep daya dukung menjadi salah satu alternatif solusi sebagai strategi dalam pengelolaan pariwisata berkelanjutan.

Untuk mengatasi permasalahan tersebut tentunya perlu dikembangkan suatu model pengelolaan yang holistik mengintegrasikan aspek-aspek yang berpengaruh terhadap daya dukung. Dalam menentukan daya dukung kawasan wisata alam perlu diperhatikan, bahwa konsep daya dukung lingkungan bukan suatu yang statis.
Definisi daya dukung lingkungan dapat diartikan beragam tergantung dari disiplin ilmu atau fokusnya. Berdasarkan definisi tersebut dapat dijelaskan bahwa daya dukung lingkungan tidak bersifat statis akan tetapi dinamis dimana kemampuan sistem dapat dikurangi atau ditambah. Rekayasa yang dilakukan dapat menggunakan teknologi. Hal tersebut menjadi lebih jelas bahwa daya dukung dapat dirubah tergantung dari sistemnya.

Dari kajian daya dukung ekologi ekowisata mangrove Blanakan dapat teridentifikasi kondisi daya dukung untuk pengelolaan pencemaran fosfat dan ammonia menjadi masalah utama yang perlu diantisipasi, pendekatan solusi untuk keberlanjutan kegiatan wisata dapat dilakukan secara langsung ataupun tidak langsung. Solusi secara langsung adalah dengan melakukan rekayasa meningkatkan daya dukung lingkungan untuk mengatasi pencemaran phosfat dan ammonia dengan teknologi pengelolaan lingkungan, atau bisa juga dengan cara melakukan secara tidak langsung yaitu menurunkan jumlah beban pencemaran dari sumbernya dengan cara memberikan edukasi bagi wisatawan. Pengelolaan merupakan suatu strategi bagaimana mempertahankan kemampuan lingkungan untuk dapat kembali pada fungsinya setelah mendapatkan stress. Pengelolaan harus bersifat holistik tidak hanya menyelesaikan permasalahan pokok akan tetapi juga ada keterkaitan dengan faktor yang lain. Sehingga perlu dikembangkan kajian yang lebih mendalam mengenai strategi pengelolaan yang tidak hanya melibatkan faktor lingkungan saja tetapi perlu mengintegrasikan dengan aspek sosial dan ekonomi.

Salah satu yang menyebabkan konsep ekowisata berdampak negatif adalah tingkat kunjungan yang melewati batas daya dukung kawasan wisata, terutama daya dukung fisik. Tingkat kunjungan yang berlebih tentu akan menurunkan kualitas kawasan ekowisata. Untuk menjaga kualitas lingkungan objek wisata dari dampak negatif diperlukan upaya pengelolaan yang terpadu. Salah satunya adalah melihat kemampuan kawasan terutama kondisi fisiknya untuk menerima jumlah maksimum pengunjung tanpa menimbulkan kerusakan atau menurunnya 
kualitas kenyamanan pengunjung. Dalam konteks ekowisata, konsep kemampuan suatu kawasan wisata untuk menerima jumlah maksimum pengunjung dinyatakan dengan konsep daya dukung (carrying capacity).

Daya dukung yang terlampaui akan menimbulkan gangguan/usikan pada ekosistem. Ekosistem yang terusik masih dapat pulih ke keadaan semula, jika gangguan tersebut tidak melebihi ambang batasnya. Daya tahan ekosistem yang besar menunjukkan bahwa ekosistem mampu menghadapi gangguan, sehingga perubahanperubahan yang terjadi akibat gangguan itu masih ditolerir bahkan ekosistem mampu pulih kembali dan menuju pada kondisi keseimbangan. Berkaitan dengan daya tahan ekosistem tersebut, di dalam ekologi terdapat istilah yang dikenal dengan resiliensi (daya lenting) ekologi. Resiliensi ekologi menunjukkan kemampuan ekosistem untuk pulih setelah terkena gangguan. Semakin cepat kondisi ekosistem itu pulih berarti semakin pendek masa pulih, semakin banyak gangguan yang dapat ditanggulangi, maka semakin besar daya lentingnya.

\section{KESIMPULAN}

Berdasarkan kajian daya dukung ekowisata mangrove Blanakan masih dapat dikembangkan menjadi tujuan wisata unggulan dengan memperhatikan dampak terhadap lingkungan baik yang sudah terjadi maupun yang akan terjadi. Pencemaran lain yang perlu diantisipasi adalah pencemaran ammonia dan limbah organik yang akan terjadi di kawasan ekowisata mangrove Blanakan. Permasalahan tersebut sangat penting untuk dicarikan solusinya karena air merupakan faktor penting yang dapat mempengaruhi kondisi kawasan konservasi, apabila terjadi penumpukan pencemaran dan tidak dilakukan pengelolaan dampak wisata tersebut maka dapat terjadi perubahan fungsi badan perairan yang menyebabkan dampak terhadap kawasan tersebut maupun pada kegiatan wisata. Strategi pengelolaan perlu dikembangkan dalam pengelolaan ekowisata mangrove Blanakan. Strategi tersebut harus bersifat holistik dan terintegrasi melibatkan aspek sosial dan ekonomi.

\section{DAFTAR PUSTAKA}

Backer, C. A. and Brink, R. C. B. V. D. 1968. Flora of Java (Spermatophyta Only) Volume III. Wolters-Noordhoff N.V. Gronngen.

Badan Pusat Statistik. 2009. Kabupaten Semarang Dalam Angka Tahun 2009.

Delin, W. and Larsen K. 2000. Zingiberaceae. Flora of China 24:322-377.

Darwis, S.N., Madjondo, A.B.D., Hasiyah, S. 1991. Tanaman Obat Famili Zingiberaceae. Badan Penelitian Dan Pengembangan Penelitian Pusat Penelitian dan Pengembangan Tanaman Industri. Bogor.

Direktorat Jendral Hortikultura. 2006. Profil Sentra Produksi Temulawak (Curcuma Xanthorrhiza Roxb). Direktorat Jendral Hortikultura, Direktorat Budidaya Tanaman Sayur dan Biofarmaka. .

Dumbois, D.M. and Ellenberg, H. 1974. Aim and Method of Vegetation Ecology. John Willey and Sons, Inc. New York

Heyne, K. 1987. Tumbuhan Berguna Indoneia: Jilid I-III. Yayasan Sarana Wana Jaya. Jakarta..

Indriyanto. 2006. Ekologi Hutan. Bumi Aksara. Jakarta.

Joy, P. P.,Thomas J.,Mathew, S., dan Skaria, B. B. 1998. Zingiberaceae Medicinal and Aromatic Plants. Aromatic and Medicinal Plants Research Station, Odakkali, Asamannoor P.Q., Kerala. India.

Kuntorini, E.M. 2005. Botani Ekonomi Suku Zingeberaceae Sebagai Obat Tradisional oleh Masyarakat di Kotamadya Banjarbaru Bioscientiae Volume 2 Nomor 2 Halaman 25-36.

Kusmana, C. 2010. Potensi Flora Indonesia

Muhlisah, F. 1999. Temu-temuan dan Emponemponan Budidaya dan Manfaatnya. Kanisius. Yogyakarta.

Odum. E. P. 1983. Basic Ecology . Saunders Collage Publishing. New York

Pandey, B. P. 2003. A Textbook of Botany: Angiosperm First Edition. S Chand and Company Ltd. New Delhi

Poernamasari,R. N. H. 1989. Distribusi dan Diversitas Gulma pada Pertanaman Kacang Tanah dan Jagung serta pada Pola Tanam Tumpang Sari. Skripsi. Fakultas Biologi 
Universitas Jenderal Soedirman Purwokerto. Purwokerto.

Siagian, S. 2009. Inventarisasi Zingiberaceae di Kawasan Agrowisata Hutan Taman Eden 100 Kabupaten Toba Samosir Sumatra
Utara. Skripsi. Departemen Biologi Fakultas Matematika dan Ilmu Pengetahuan Alam Universitas Sumatra Utara. Medan. 